\title{
VÝZNAM DOPRAVY V LOGISTICE PODNIKU
}

\author{
Marta Wilczková, Petr Vlček
}

\section{Klíčová slova:}

doprava, přeprava, koncepce celkových logistických nákladů, dodavatelsko-odběratelský řetězec

\section{Key words:}

traffic, transport, total logistics costs, supplier-customer chain

\begin{abstract}
Abstrakt
Článek se zabývá významem dopravy a dopravních systémů v rámci logistického řízení dodavatelsko-odběratelských řetězců. Vhodné řízení přepravních nákladů je součástí řízení celkových logistických nákladů podniků. Cílem podniku je navýšení hodnoty produktu pro zákazníka př́i současném snížení celkových nákladů a tak podnik může lépe uplatnit konkurenční výhodu, která je spojena s optimálním využitím dopravních a přepravních procesů. $\mathrm{V}$ důsledku rozvoje informačních a komunikačních technologií využívaných pro řízení podnikové a mimopodnikové dopravy mohou podniky lépe využívat omezené zdroje a informace, které umožňují podporovat logistické cíle podniku, kdy se v důsledku lepší spolupráce s klíčovými partnery vytvoří logistická sít', která umožní zvýšit efektivitu jednotlivých podniků.
\end{abstract}

\begin{abstract}
The article deals with the importance of transport and transport systems within the logistics management of supplier-customer chains. Suitable management of transport costs constitutes the part of the management of total logistics costs of enterprises. The aim of the enterprise is to increase the value of the product for the customer while reducing overall costs so that the enterprise can better apply the competitive advantage that is associated with the optimal use of traffic and transport processes. As the result of the development of information and communications technologies used for the management of the transport within and out the enterprise, the companies can make better use of the limited resources and information, which enable the support of the logistics objectives of the company. Due to better cooperation with key partners the logistics network will be developing and will enable to increase the efficiency of individual enterprises.
\end{abstract}

\section{Úvod}

V souvislosti s globalizujícím se světem je v jednotlivých sektorech ekonomiky patrný značný převis nabídky nad poptávkou, vzrůstá míra konkurence nejenom na trzích výrobků a služeb, ale také se zvyšuje konkurence mezi jednotlivými regiony. Také postupné sjednocování Evropy přispívá $\mathrm{k}$ rychlejšímu vytváření významných rozdílů mezi regiony. Rozvoj jednotlivého regionu, který je bezprostředně závislý na rozvoji dopravního systému a stavu dopravní infrastruktury, je důležitým atributem rozvoje jakéhokoliv územního celku na jedné straně a současně je výsledkem a souhrnem společného působení jednotlivých subjektů a procesů, které jsou součástí regionu.

Optimalizace a řízení přepravních nákladů v podniku je součástí plánování podniku, kde cílem logistické činnosti je komplexní uspokojení specifických potřeb zákazníků v 
optimálním čase. Výrazným znakem současné logistiky je růst počtu a kvality vztahů a vazeb jednotlivých článků logistického řetězce $\mathrm{v}$ globálním měřítku. Jednotlivé subjekty hledají stále nové cesty, metody a prostředky, které by jim umožnily prosadit se v silně konkurenčním prostředí. Souběžně s trvalým nárůstem celkového objemu přepravovaného zboží se však stále naléhavěji objevuje potřeba přemístit zboží v přesně stanoveném množství a termínech, za přijatelné ceny, s minimálním ekologickým zatížením prostředí, a přizpůsobit se konkrétním individuálním potřebám zákazníků.

\section{Význam a postavení sektoru dopravy}

Doprava patří mezi nejdůležitější faktory, které mají bezprostřední vliv na podporu růstu v moderních ekonomikách. Ministerstvo dopravy ČR v rámci dokumentu Koncepce výzkumu a vývoje v resortu dopravy na léta 2006 - 2010 uvádí, že ačkoliv poptávka po dopravě neustále narůstá, není možné ji řešit pouze budováním nové infrastruktury. V koncepci se zdůrazňuje nutnost „..lépe využívat, optimalizovat, organizovat stávající dopravní systémy tak, aby splňovaly požadavky udržitelného rozvoje a vzrůstající poptávku po přepravě“. V dokumentu se poukazuje na potřebu udržitelnosti moderních dopravních systémů z hlediska:

- ekonomického,

- sociálního,

- ekologického,

- obranného.

Eisler (2008) v publikaci Ekonomika dopravních služeb a podnikání v dopravě vymezuje následující funkce dopravy:

- dominantní funkce - přemíst'ování zboží a osob,

- stimulační funkce - investice do dopravní infrastruktury iniciují oživení ekonomiky,

- sociálně stabilizační - při racionalizaci dopravní soustavy musí být brán ohled na udržení sociálního smíru,

- substituční - doprava může nahrazovat skladování a současně komunikační technologie mohou záporně ovlivnit dopravu,

- komplementární.

Tabulka 1 Přepravní výkony (mil. tkm)

\begin{tabular}{|l|c|c|c|c|c|c|c|c|}
\hline Doprava & \multicolumn{10}{|c|}{ Rok } \\
\hline & $\mathbf{2 0 0 2}$ & $\mathbf{2 0 0 3}$ & $\mathbf{2 0 0 4}$ & $\mathbf{2 0 0 5}$ & $\mathbf{2 0 0 6}$ & $\mathbf{2 0 0 7}$ & $\mathbf{2 0 0 8}$ & $\mathbf{2 0 0 9}$ \\
\hline Železniční & 15810 & 15862 & 15091 & 14866 & 15779 & 16304 & 15437 & 12644 \\
\hline Silniční & 45059 & 46564 & 46010 & 43447 & 50369 & 48141 & 50877 & 44955 \\
\hline Vodní & 587 & 509 & 409 & 779 & 818 & 898 & 863 & 633 \\
\hline Potrubní & 1717 & 1820 & 1902 & 2259 & 2291 & 2079 & 2315 & 2156 \\
\hline
\end{tabular}

Zdroj: upraveno podle ČSÚ

Doprava tak představuje významný úkol k řešení v rámci všech vyspělých ekonomik a proto je potřebné dopravní proces aktivně řídit, regulovat a využívat prvky liberální ekonomiky. Dopravní politika Evropské unie vytčená v Bílé knize: „Dopravní politika EU pro rok 2010 čas rozhodnout“ jednoznačně specifikuje základní cíl, kterým je podpora udržitelného rozvoje dopravy zboží a osob, harmonizace podmínek pro všechny dopravní obory s důrazem na internalizaci externalit. 
Dokument Dopravní politika České republiky na léta 2005-2013 uvádí, že v důsledku globalizačních vlivů dochází ke zvětšování vzdálenosti mezi místem výroby a spotřeby a v rámci nákladní dopravy se proto přepravci snaží minimalizovat logistické náklady, preferují rychlost a přesnost dodávky a vlivem toho jsou logistické systémy orientovány především na silniční nákladní dopravu.

\section{Obrázek 1 Výkon letišst’ v letecké obchodní nákladní dopravě (t)}

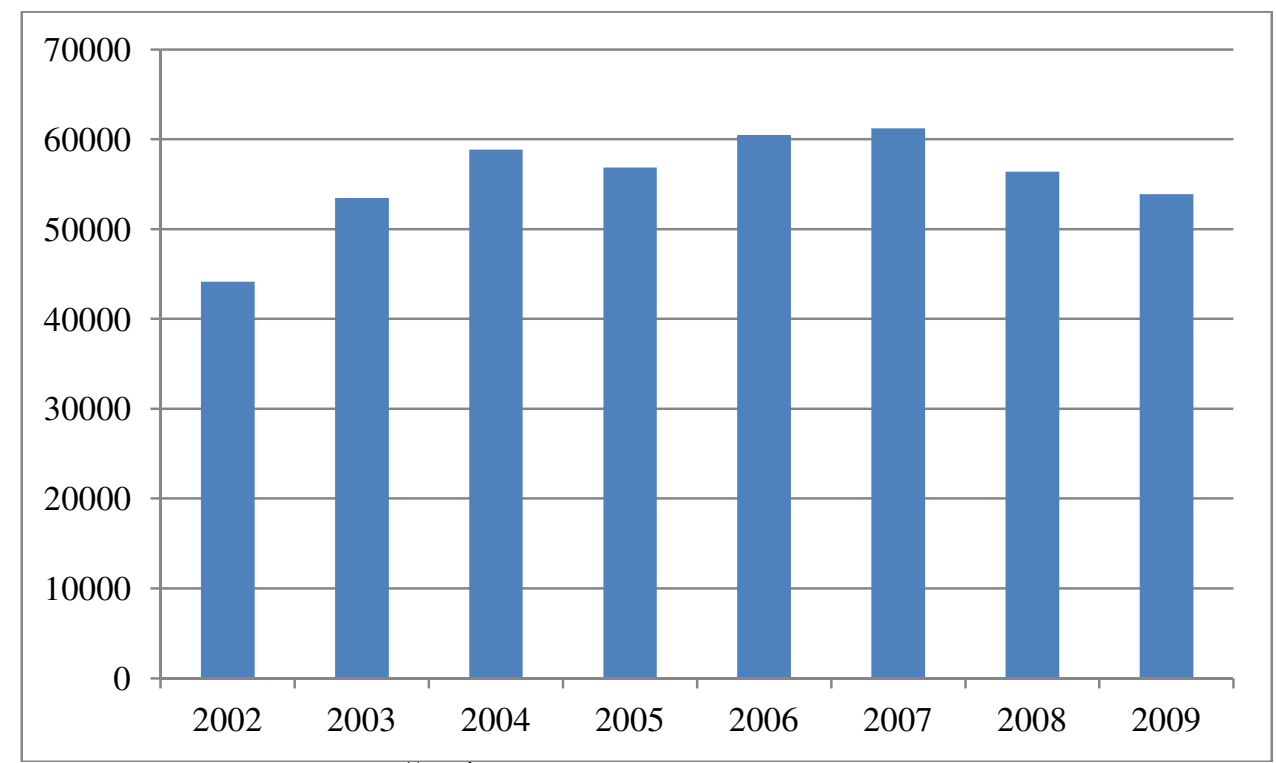

Zdroj: upraveno podle ČSÚ

Novák et al. (2005) vymezují sféry zájmů jednotlivých subjektů, které musí koordinovat postup v rámci dopravního sektoru, jedná se o následující sféry:

- sféra tržní - uživatelé dopravy, operátoři dopravy, vláda,

- sféra infrastruktury - uživatelé dopravy, operátoři dopravy, infrastrukturní agentury,

- sféra dopravní politiky - vláda, uživatelé dopravy, operátoři dopravy, infrastrukturní agentury.

Ve snaze o kooperaci a koordinaci společného postupu musí jednotlivé subjekty čelit faktorům, které významným způsobem ovlivňovali a v budoucnu budou stále významněji ovlivňovat vývoj v rámci dopravního sektoru. Novák et al. (2005) uvádějí nejdůležitější faktory, které je možné rozdělit do následujících skupin:

- politické a legislativní faktory,

- ekonomické faktory,

- sociálně-kulturní faktory,

- technologické a ekologické faktory.

\section{Politické a legislativní faktory.}

Za nejvýznamnější politický aspekt autoři považují problémy vznikající $\mathrm{v}$ důsledku geografických disparit, které mohou být prríčinou vzniků konfliktů, v evropském měřítku jedná se především o vývoj a dynamiku přepravních proudů ve směrech západ-východ a centrum-periferie. Dalším faktorem je harmonizace legislativy a začleňování ekologických prvků do právních norem jednotlivých zemí. 


\section{Ekonomické faktory}

Autoři očekávají, že rozvoj ekonomiky vyvolá expanzi dopravního sektoru, avšak zdůrazňují, že existují problémy, které mohou tento rozvoj ovlivnit, jedná se především o:

- omezenou kapacitu dopravní infrastruktury,

- přepravní náklady,

- ohled na životní prostředí.

Za problém financování investic do dopravy autoři nepovažují absolutní nedostatek prostředků, ale vidí ho spíše $\mathrm{v}$ nevyváženosti dopravního sektoru a v chování uživatelů dopravní infrastruktury. V zájmu ekonomické racionality je potřebné uplatňovat v rámci dopravního sektoru praxi kvantifikace kladných i záporných externalit a následně redistribuci těchto účinků mezi různé uživatele jakož i mezi neuživatele. V oblasti plánování dopravního sektoru, autoři uvádějí jako problém nedostatečnou schopnost vyrovnat se s ekonomickými cykly, naprŕíklad v období růstu se uplatňují rozsáhlé plány investic, ale s nástupem recese se nahrazují úspornou variantou a potom dochází $\mathrm{k}$ poklesu investic a v období následného vzestupu dochází ke kapacitním problémům.

\section{Sociálně-kulturní faktory}

Autoři uvádějí, že rozvoj dopravního sektoru ovlivňují změny související se standardizací životních podmínek, odbouráváním kulturních barier $\mathrm{v}$ evropské společnosti, včetně narůstajících konzumních prvků $\mathrm{v}$ ekonomicky méně vyspělých zemích, jež ve svých důsledcích vedou k růstu hybnosti a ke zvýšení podílu turistické a rekreační dopravy.

Dále dopravu mohou ovlivnit všechny formy migrace:

- sociálně-etnická,

- vnitřní migrace - v důsledku měnící se skladby bydlišt' a pracovišst',

- migrace sezónní, kdy relativně dosud levná doprava umožňuje rozvoj masové turistiky.

Automobilizace je podle autorů dalším problémem rozvoje dopravního sektoru, protože přesahuje u uživatelů pouhou dopravní funkci, ale plní úlohu pracovny, skladovacího prostoru, prostředku rekreace, sociálního symbolu.

\section{Technologické a ekologické faktory}

Autoři uvádějí, že rozvoj v oblasti se především zaměřuje na zvyšování výkonů, efektivnosti provozu dopravních prostředků, na omezování škodlivých účinků, na standardizaci a bezpečnost. V oblasti použití informačních technologií je možné očekávat pokračující vývoj v oblasti výpočetní techniky a telematiky. V rámci meziměstské dopravy autoři očekávají problémy způsobené v důsledku zvýšeného nároku na kapacitu dopravních systémů a zvýšení kapacit silnic vyššího řádu (především dálnic), a řešení se jeví jako technicky i ekologicky obtížné. Za další problém autoři považují změny $\mathrm{v}$ urbanistické struktuře, které budou mít dopad na odpovídající změny $\mathrm{v}$ síti dopravních cest a v modernizaci dopravních systémů. Faktor ekologie ovlivňuje rozvoj dopravy především $\mathrm{v}$ oblasti stavebních nákladů a prodloužení dopravních tras $\mathrm{v}$ důsledku nákladnějších projektových řešení. S tímto aspektem nepřímo souvisí potřeba snížení ztrát na životech a zdraví lidí při dopravních nehodách. Ekologické aspekty mají také stále větší dopad na tvorbu legislativy.

\section{Trendy a kritické faktory logistického řízení}

Grant et al. (2006) identifikují hlavní trendy a faktory v současné logistice, které mají z hlediska vývoje logistiky a logistické praxe zásadní význam. Jedná se o následující oblasti:

- řízení dodávkových řetězců a integrované řízení kanálů,

- řízení orientované na kvalitu (TQM), 
- př́ístupy Just-in-Time,

- informační systémy,

- reengineering,

- časový faktor konkurence,

- ekologické otázky a zpětná logistika.

Autoři jsou přesvědčeni, že management každého podniků by měl tyto faktory zahrnout do procesu strategického plánování a uplatnit logistiku jako významný prvek v získání významné konkurenční výhody podniku.

Řízení dodávkových řetězců. Distribuční kanál podniku je nutné považovat a analyzovat jako celek a proto by měl management zahrnout řízení dodávkového řetězce do strategického plánovacího procesu, ve kterém je potřebné rozhodnout o tom, do jaké míry je nutné, aby dodávkový řetězec podléhal vlastnímu řízení a také kdo a kde by měl vykonávat vybrané činnosti v rámci dodávkového řetězce.

Základem řízení dodávkového řetězce je snaha jak o zlepšení efektivnosti kanálu jako celku tak snaha o zvýšení efektivnosti jeho řízení. Podnik může uplatnit tyto snahy především uplatněním:

- kvalitnějšího sdílení informací,

- efektivního rozmíst’ování zásob v rámci kanálu,

- koordinovaného rozhodování ve všech klíčových obchodních procesech.

Významným pojmem v oblasti řízení dodávkových řetězců je integrované ř́zení kanálu, které se zaměřuje na propojování programů a činností všech členů kanálu, přičemž cílem je dosažení vyšší úrovně spokojenosti zákazníkủ. Pro uplatnění koncepce integrovaného řízení kanálu autoři navrhují využít následující možnosti:

- implementovat strategie integrace kanálu,

- převzít vůdčí roli v kanálu,

- vytvořit aliance s vůdčími členy kanálu

- zaměřit se na vybrané činnosti, které přinášejí největší efekt.

Total quality management (TQM). Kvalita představuje významný aspekt rozhodování a také výkonu každého podniku. Podnik se na jedné straně snaží snižovat náklady nebo zkracovat dobu cyklu dodání zboží na trh, na druhé straně je kvalita významným aspektem zákaznického servisu a jakékoliv snížení kvality servisu může vést k poklesu spokojenosti případně ke snížení prodeje. Negativní dopad změn v úrovni kvality nabízeného zákaznického servisu může v konečném důsledku převýšit úspory dosažené snížením nákladů.

Just-in-time. Jedná se o uplatňování filozofie, snahou které je snižování ztrát, redundancí a neefektivit v rámci celého výrobního systému. Grant et al. (2006) uvádějí, že v rámci dodávkového řetězce se tento přístup zaměřuje na odstraňování ztrát a redundancí mezi obchodními partnery, kteří jsou součástí dodávkového řetězce, to znamená, že se jedná o rozhodování a zamezování ztrát a redundancí, které se netýkají bezprostředně vnitřního prostředí podniku, ale dlouhodobého společného postupu obchodních partnerů.

Informační systémy. Autoři označují logistické činnosti za tzv. transakčně náročné, to znamená, že jednotlivé dílčí činnosti (např. příjem zboží, skladování, plnění objednávek nebo dodávky zboží) vytvářejí velké objemy dat. Uvedená data je možné využít jak pro hodnocení reálného logistického výkonu, ale také v rámci identifikace oblastí pro zlepšení výkonu. Z uvedeného je zřejmé, že sběr, uchovávání, analýza, distribuce určeným uživatelům a aplikace vhodných dat má velký význam pro strategický plánovací proces. 
Reengineering. Grant et al. (2006) považují reengineering za př́stup, který umožňuje podniku vytvořit nové systémy a procesy, které nejsou pouhou modifikací dosavadních systémů a procesů, ale jedná se o zásadní změny a kvalitativně jiné řešení. Reengineering je možné využít především u procesů, které jsou transačně náročné nebo mají vyšší nároky na pracovní sílu.

Časový faktor konkurence. Podle Granta et al. (2006) se časový faktor konkurence v podniku může týkat především zkracování doby cyklu objednávek, urychlování podávání objednávek nebo rychlejšího uvádění nových výrobků na trh, takovým způsobem, aby se zvýšila efektivnost dodávkového řetězce jako celku. Využití časového aspektu konkurence je možné dosáhnout prostřednictvím:

- lepší spolupráce s dopravci, dodavateli a zákazníky díky sdílení aktuálních informací,

- zvýšení přesnosti informací,

- zjištování oblastí a činností, které nejsou dostatečně efektivní.

Ekologické otázky a zpětná logistika. Autoři jsou přesvědčeni, že ekologickým faktorům by se měla věnovat významná pozornost $\mathrm{v}$ rámci procesu strategického plánování, protože v celém světě se zvyšuje rozsah legislativních opatření v této oblasti na jedné straně a na druhé straně se zvyšuje poptávka zákazníků po zboží a službách, které mají minimální dopady na životní prostředí. Mezi nejdůležitější otázky, řešené mezi odborníky z praxe, vědci a v neposlední míre politiky, patří:

- recyklace,

- vhodné řízení a likvidace nebezpečných materiálů,

- balicí materiály pro opětovné použití,

- použití obnovitelných zdrojů, uchování energetických zdrojů.

Z uvedeného je zrejejé, že logistické řízení, součástí kterého je optimální využívání dopravního systému a přepravních služeb, jak v rámci poptávky po vnitropodnikové a také mimopodnikové dopravě, se jeví jako významná možnost pro získání konkurenční výhody v oblasti řízení celkových nákladů podniku.

\section{Postavení dopravy v logistice}

Úkolem dopravy je fyzické přemístění produktu z místa výroby do místa, kde je výrobek potřebný, v logistice se uvádí pod pojmy přínos místa a přínos času. Přemíst'ování se realizuje v základních fázích reprodukčního procesu, kterými podle Šulgana et al. (2008) jsou:

- doprava ve sféře výroby - uspokojuje potřeby spojené s technologií výroby, dělbou činností, kooperací a specializací výroby mezi jednotlivými fázemi výroby až do finálního produktu,

- doprava ve sfére oběhu - jedná se o realizaci pohybu toku zboží v koncových oblastech reprodukčního procesu,

- doprava ve sféře spotřeby - uspokojuje potřeby, které vznikli v důsledku změny místa a času na straně zákazníka.

Koncepce celkových nákladů je základním prvkem v rámci efektivního řízení logistického systému v podniku. Organizace by se neměli soustřed'ovat pouze na jednotlivé izolované logistické činnosti, ale měli by se snažit minimalizovat celkové náklady logistických činností. Snížení nákladů v jedné oblasti (omezování skladových prostor), může vyvolat zvýšení 
nákladů v další oblasti (doprava), a to vlivem změny vstupů zapříčiněných snížením nákladů v předcházející oblasti.

Cílem logistiky je minimalizovat celkové náklady při udržení stanovené úrovně zákaznického servisu. Management by měl rozhodovat na základě analýzy informací o nákladových vazbách. Klíčové logistické činnosti v organizacích nabízejících služby nemusí nutně patřit do kompetence útvarů logistiky, ale je potřebné si uvědomit, jak významně ovlivňují logistický proces organizace jako celku. Autoři Sixta a Mačát (2005) uvádějí, že podnik by měl zabezpečit jednotlivé oblasti logistického systému mezi, které patří:

- úroveň zákaznického servisu,

- přepravní náklady,

- náklady na udržování zásob,

- skladovací náklady,

- množstevní náklady,

- náklady na informační systém.

\section{Závěr}

Rozvoj nových technologií, rychlejší komunikace má významný vliv na rozvoj tržního prostředí a proto je zabezpečení stabilního postavení podniku v rámci rychle se měnícího konkurenčního prostředí základním úkolem managementu. Logistická praxe ukazuje, že sebelepší individuální řešení problémů vede jenom těžko $\mathrm{k}$ úspěšnému řešení, pokud je uplatněno izolovaně. Logistický řetězec, součástí kterého jsou dodavatelé materiálů, producenti, distributoři a také finální zákazník, se skládá z velkého počtu prvků a právě doprava tvoří spojení mezi těmito články.

Moderní logistická praxe proto směřuje ke komplexnímu řešení problémů, $\mathrm{k}$ integraci logistických řetězců, aby bylo plně využito synergického efektu. V pojetí integrované logistiky se tato realita odráží v nepřetržité snaze redukovat časové ztráty při neustálém zlepšování kvality poskytovaných služeb a snižování nákladů. Významnou úlohu hraje komplexnost poskytovaných přepravních služeb při vysoké úrovni jejich spolehlivosti.

\section{Literatura:}

[1] Dopravní politika České republiky na léta 2005-2013. On-line http://www.mdcr.cz/cs/Strategie/Dopravni_politika/. (21. 6. 2010).

[2] EISLER, J. Ekonomika dopravních služeb a podnikání v dopravě. Praha: Oeconomica nakladatelství VŠE. 2008. ISBN 978-80-245-1416-1.

[3] GRANT D., B., LAMBERT, D., M. a kol. Fundamentals of Logistics Management. European edition. London: The McGraw Hill, 2006. ISBN 100-07-710894-9.

[4] Koncepce výzkumu a vývoje v resortu dopravy na léta 2006 -2010. On-line http://www.mdcr.cz/NR/rdonlyres/3E7F5755-7513-4DA8-BC4D-

6665FC10C52E/0/koncepce_VaV.pdf. (21. 6. 2010).

[5] NOVÁK, R., PERNICA, P., SVOBODA, V., ZELENÝ, L. Nákladní doprava a zasílatelství. Praha: ASPI, a.s., 2005. 412 s. ISBN 80-7357-086-6.

[6] Nákladní doprava - časové rady. On-line http://www.czso.cz/csu/redakce.nsf/i/nakladni_doprava_casove_rady. (7. 6. 2010).

[7] SIXTA J., MAČÁT V. Logistika - teorie a praxe. Brno: CP Books, 2005. 315 s. ISBN 80-251-0573-3. 
[8] ŠULGAN, M., GNAP, J., MAJERČÁK, J. Postavenie dopravy v logistike. Žilina: EDIS vydavatel'stvo ŽU, 2008. 238 s. ISBN 978-80-8070-784-2.

Klasifikace JEL: M11, M20

Ing. Marta Wilczková, Ing. Petr Vlček

Katedra logistiky

Obchodně podnikatelská fakulta v Karviné

Slezská univerzita v Opavě

Univerzitní nám. 1934/3

73340 Karviná

wilczklova@opf.slu.cz,vlcek@opf.slu.cz 